\title{
Biomass Waste and Low Rank Coal Gasification Technology with Carbon Capture System to Optimize A Clean Energy Production as An Alternative Solution to Achieve Energy Security in Indonesia
}

\author{
Ardian N. Baskoro $^{1 *}$, Odara E. Aptari ${ }^{1}$ \\ ${ }^{1}$ Chemical Engineering Department, Faculty of Industrial Technology, Institut Teknologi Bandung \\ Jalan Ganesha No. 10, Bandung 40132, Indonesia \\ Received 30 June 2020; Accepted 8 August 2020 \\ Available online 31 August 2020
}

\begin{abstract}
A shift into a more developed country means an increase in various aspects of economy, energy, social, and even environment. For Indonesia, a major change that the country needs to face is the increase of energy demand of 7\% every year, reaching a final average expected energy consumption of 497.77 MTOE in 2050. In order to fulfil all upcoming energy demands and achieve energy security, it is crucial to utilize the available abundant resources that the country possesses. Two of these potential resources include coal (22.6 billion tons) and biomass $(32.6 \mathrm{GW})$. Gasification is an alternative clean technology that can utilize low rank coal or biomass to convert it into syngas. The quality of syngas was characterized using the $\mathrm{H}_{2} / \mathrm{CO}$ ratio parameter. The greater the carbon density in a material, the greater $\mathrm{H}_{2} / \mathrm{CO}$ ratio will be. However, syngas produced from conventional gasification still emits $\mathrm{CO}_{2}$. Since $\mathrm{CO}_{2}$ is still emitted in coal gasification technology, a carbon capture system called HyPr-RING process is implemented as an alternative to reduce $\mathrm{CO}_{2}$ and increase the quality of syngas up to $91 \%$ volume of $\mathrm{H}_{2}$. The process uses $\mathrm{CaO}$ as a sorbent to capture $\mathrm{CO}_{2}$ and convert it into $\mathrm{CaCO}_{3}$ in a gasifier. Then, the $\mathrm{CaCO}_{3}$ is calcinated in a calciner to release back $\mathrm{CaO}$ that is recycled to capture more of the $\mathrm{CO}_{2}$. Aside from the high availability of coal and biomass, $\mathrm{CaO}$ as a major substance used in the $\mathrm{CO}_{2}$ capture process is also abundant in Indonesia (2,156 billion tons). This technology innovation is also economically feasible as it creates a net profit of USD 58,215 and ROI of $11 \%$.
\end{abstract}

Keywords: biomass, calcium, carbon capture, coal, gasification

\section{Introduction}

Indonesia has been declared as one of the fastest developing countries in the world with a large population of 267 million people. A projected increase in population and GDP will also be accompanied with an increase in energy consumption and demand. Even through the years of 2012 up to 2017, Indonesia's electrical consumption has increased by $7 \%$ every year. This projection urges the country to find the proper technology which utilizes abundant resources in order to fulfill the rapidly increasing energy demand, achieving energy security.

\subsection{Energy Security and Indonesia's Current Condition}

According to International Energy Agency, energy security is defined as the abundant, continuous and uninterrupted availability of energy sources at an affordable price and accessible state. As Indonesia is known to be rich with various types of energy sources, it is extremely crucial for the country to be able to utilize and optimize all of the energy sources, which include oil, gas, coal, and renewable energy in achieving its energy security. This is a forefront necessity at the moment as Indonesia continues to grow and thrive in shifting into a more developed country.

*Corresponding author

E-mail address: ardian.nugra@gmail.com 
According to Indonesia Energy Outlook 2019, analyzing the energy sector for the last few years, Indonesia has been fueled with various energy supplies, which include oil, gas, coal, and renewable energy. In 2018, the total primary energy production of all these sources reaches up to 411.6 MTOE. As Indonesia is known as the fourth largest producer of coal in the world, it has exported around 261.4 MTOE of its coal production. Accumulating the sources, the total final energy consumption in 2018 is 114 MTOE.

Unfortunately, with a projected increase in population for the upcoming years, the Ministry of Energy and Mineral Resources has predicted that energy demand will rise every year with an annual growth of $5.0 \%, 4.7 \%$, and $4.3 \%$ respectively for three different scenarios, which are Business as Usual (BaU), Sustainable Development (PB), and Low Carbon (RK) (Suharyati et al., 2019). The growth of energy demand in 2020 up to 2050 is shown in Figure 1.

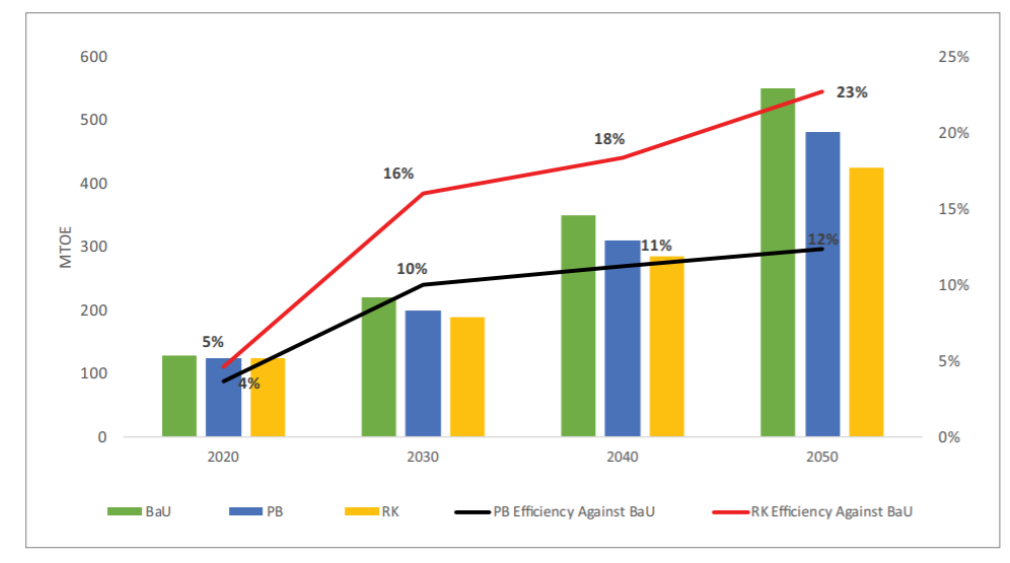

Figure 1. Comparison of final energy demand three scenarios (Suharyati et al., 2019).

Based on the comparison predicted by the ministry, the final energy demand of Indonesia in 2050 will reach 548.8 MTOE, 481.1 MTOE, and 424.4 MTOE, respectively (Suharyati et al., 2019). Regarding this prediction, Indonesia is also well known for its energy potential from various abundant resources. Nevertheless, the increasing concern about global warming issues has led officials to shift the country's energy demand to the renewable ones. This affects the non-renewable sources of energy in Indonesia such as coal to be less favorable.

\subsection{Coal Reserves and Its Potential}

Examining the potential supply of energy sources, one major energy resource that has been around as early as the 1970s is coal. Indonesia is known as the fourth largest coal producer in the world with a total reserve of 22.6 billion tons, which hoards around $2.2 \%$ of the total global coal reserve. Coal is also seen as a main source of economic income (USD 2.17 million) for the country as it is declared for being the second largest coal exporter globally. Based on the Presidential Decree No. 22/2017 which releases a national plan of energy utilization or Rencana Umum Energi Nasional, it is projected that by 2025 and 2050, coal will still be one of the primary energy sources, covering 30\% (119.8 MTOE) and 25.3 $\%$ (255.9 MTOE) of the total energy production respectively (RUEN, 2017).

Aside from its abundance, coal technology is also the cheapest source of energy amongst the others and that becomes the major reason why Indonesia still depends heavily on coal. Unfortunately, even though the coal reserve in Indonesia is one of the biggest in the world, the percentage of medium to high-ranked coal is decreasing throughout the years and is predicted to be extinct in 2048. This upcoming complication pushes the urgency to utilize low-ranked coal which has numerous drawbacks, including high water content, low heat value, low efficiency, and high transportation cost. Moreover, the burning of low-ranked coal results in a relatively high emission of $\mathrm{CO}_{2}$ compared to other energy resources, 
rapidly stimulating the effects of global warming. The emission factor of average coal reaches up to $99,718 \mathrm{~kg} \mathrm{CO}_{2} / \mathrm{TJ}$. The different emission factor of coal according to its quality is shown in Figure 2.

Figure 2. Comparison of coal emission factor (Kementerian Energi dan Sumber Daya Mineral, 2016).

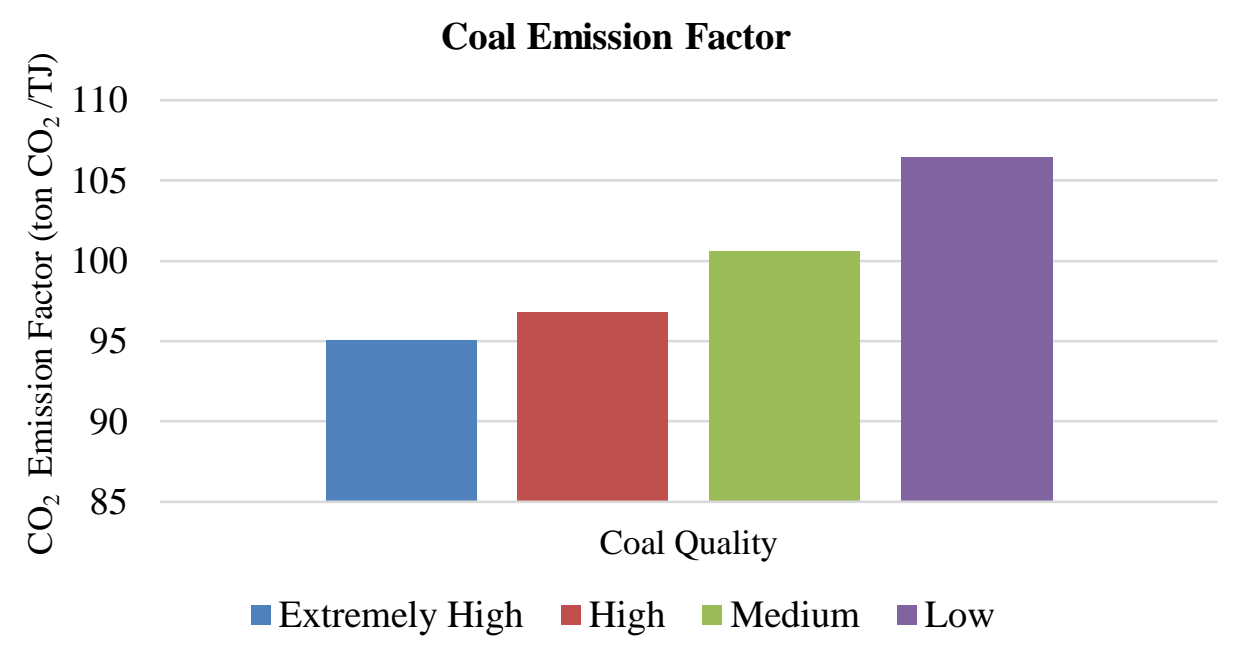

Correlating the emission factor with its quality, it can be seen how the lower the quality of coal, the higher the emission factor. With a total coal power plant capacity of $25.7 \mathrm{GW}$, electricity generation through coal utilization has contributed around $68 \mathrm{Gtons} / \mathrm{year}$ of $\mathrm{CO}_{2}$ emission. According to Indonesia's Nationally Determined Contribution 2016, this is contradictory to Indonesia's plan in reducing its $\mathrm{CO}_{2}$ emission to $26 \%$ in 2020 and $29 \%$ in 2030 . Therefore, it is extremely crucial to discover a cleaner and more efficient technology to utilize the abundance of coal as a way to achieve Indonesia's energy security.

\subsection{Biomass and Its Potential}

Besides coal, there is another potential abundant source of energy in Indonesia, which is biomass. Biomass is considered to be an alternative fuel with a neutral $\mathrm{CO}_{2}$ emission. It is available in a huge amount in Indonesia with a potential up to $32.6 \mathrm{GW}$. The potential of various kinds of biomass is shown in Figure 3. Palm oil, rice, and rubber have the highest potential amongst other biomass resources in Indonesia.

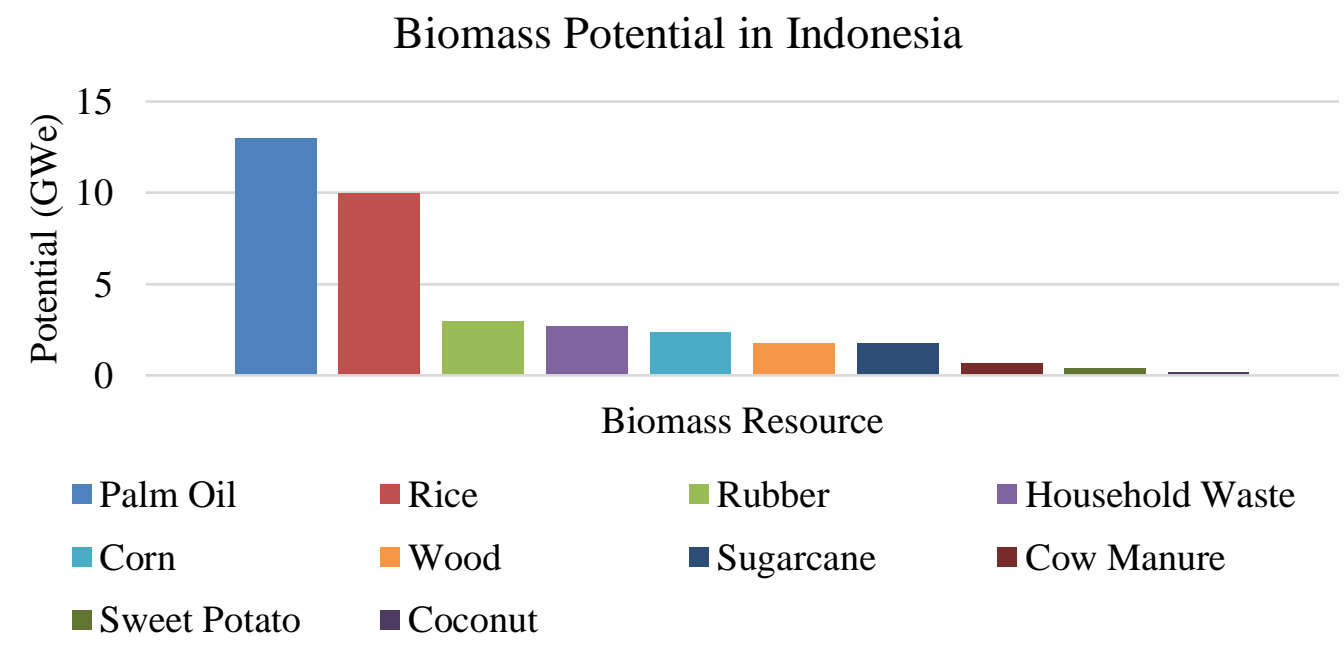

Figure 3. Comparison of biomass potential in Indonesia (Gielen, Saygin, \& Rigter, 2017; Tun et al., 2019).

1.4 Objective of the Study 
As Indonesia approaches a significant increase in population and energy consumption, energy security is stated to be one of the most crucial aspect that the country needs in order to thrive. This concern can be answered through the utilization of Indonesia's big coal reserves of 22.6 billion tons. Unfortunately, with various new policies and regulations that are implemented and signed revolving ways to reduce global warming and $\mathrm{CO}_{2}$ emission, coal is not considered to be a clean technology. Moreover, the quality of the coal produced is considered to be low-ranked coal. Therefore, in order to maximize the utilization of coal potential in Indonesia, a new method and technology is needed to advance the quality of the low-ranked coal and produce a low $\mathrm{CO}_{2}$ emission. Other than coal, Indonesia also possesses a promising potential of biomass that can be used as an energy resource.

The objective of this study is to analyze and examine the feasibility of gasification technology that is equipped with a carbon capture system to produce a higher quality of coal with lower $\mathrm{CO}_{2}$ emission. Moreover, considering the potential of biomass in Indonesia, this study also analyzes the feasibility of the implementation of the same technology using biomass as a different feedstock to create a source of energy with a neutral $\mathrm{CO}_{2}$ emission. With the appropriate technology, coal and biomass can both be reliable resources for Indonesia to achieve energy security. This analysis is achieved through a series of literature review.

\section{Coal and Biomass Gasification Technology}

Through the thermochemical energy conversion process, carbonaceous materials can be utilized using three different processes which are gasification, pyrolysis, and direct combustion to gain new form having more significant energy. Among the three processes, gasification is the most efficient process (Purohit, 2009). Gasification is basically a process for converting all types of carbon-based materials into gas products that have chemical heat values (Guan, 2017). This gas is commonly referred to as synthetic gas (syngas) and contains several constituent gas components namely carbon monoxide $(\mathrm{CO})$, hydrogen $\left(\mathrm{H}_{2}\right)$, methane $\left(\mathrm{CH}_{4}\right)$, a small portion of low chain hydrocarbons $\left(\mathrm{C}_{\mathrm{x}} \mathrm{H}_{\mathrm{y}}\right)$, carbon dioxide $\left(\mathrm{CO}_{2}\right)$, steam $\left(\mathrm{H}_{2} \mathrm{O}\right)$, and nitrogen $\left(\mathrm{N}_{2}\right)$ contained in the atmospheric air supplied to the process (Pereira et al., 2012). Therefore, this gasification technology offers a form of energy conversion from coal or biomass to electrical energy and/ or chemical energy through a very clean process.

In the gasification process of both coal and biomass, there are several reaction stages involved to convert the feedstock to the product gas. This reaction takes place along a separate reactor over the temperature difference. But in general, the reaction of carbonaceous compounds that occur during the gasification process is shown in Table 1. 
Table 1. Typical gasification reactions at $25^{\circ} \mathrm{C}$ (Basu, 2013b).

\begin{tabular}{llr}
\hline Reaction Type & Reaction & $\Delta \mathrm{H}^{\circ} 298$ \\
\hline Carbon Reactions & $\mathrm{C}+\mathrm{CO}_{2} \leftrightarrow 2 \mathrm{CO}$ & $+172 \mathrm{~kJ} / \mathrm{mol}$ \\
R1 (Boudouard) & $\mathrm{C}+\mathrm{H}_{2} \mathrm{O} \leftrightarrow \mathrm{CO}+\mathrm{H}_{2}$ & $+131 \mathrm{~kJ} / \mathrm{mol}$ \\
R2 (Water-gas or steam) & $-74.8 \mathrm{~kJ} / \mathrm{mol}$ \\
R3 (Hydrogasification) & $\mathrm{C}+2 \mathrm{H}_{2} \leftrightarrow \mathrm{CH}_{4}$ & $-111 \mathrm{~kJ} / \mathrm{mol}$ \\
R4 & $\mathrm{C}+0.5 \mathrm{O}_{2} \rightarrow \mathrm{CO}$ & \\
Oxidation Reactions & & $-394 \mathrm{~kJ} / \mathrm{mol}$ \\
R5 & $\mathrm{C}+\mathrm{O}_{2} \rightarrow \mathrm{CO}_{2}$ & $-284 \mathrm{~kJ} / \mathrm{mol}$ \\
R6 & $\mathrm{CO}+0.5 \mathrm{O}_{2} \rightarrow \mathrm{CO}_{2}$ & $-803 \mathrm{~kJ} / \mathrm{mol}$ \\
R7 & $\mathrm{CH}+2 \mathrm{O}_{2} \leftrightarrow \mathrm{CO}_{2}+2 \mathrm{H}_{2} \mathrm{O}$ & $-242 \mathrm{~kJ} / \mathrm{mol}$ \\
R8 & $\mathrm{H}_{2}+0.5 \mathrm{O}_{2} \rightarrow \mathrm{H}_{2} \mathrm{O}$ & \\
Shift Reaction & & $-41.2 \mathrm{~kJ} / \mathrm{mol}$ \\
R9 & $\mathrm{CO}+\mathrm{H}_{2} \mathrm{O} \leftrightarrow \mathrm{CO}_{2}+\mathrm{H}_{2}$ & \\
Methanation Reactions & & $-247 \mathrm{~kJ} / \mathrm{mol}$ \\
R10 & $2 \mathrm{CO}+2 \mathrm{H}_{2} \rightarrow \mathrm{CH}_{4}+\mathrm{CO}_{2}$ & $-206 \mathrm{~kJ} / \mathrm{mol}$ \\
R11 & $\mathrm{CO}+3 \mathrm{H}_{2} \leftrightarrow \mathrm{CH}_{4}+\mathrm{H}_{2} \mathrm{O}$ & $-165 \mathrm{~kJ} / \mathrm{mol}$ \\
R14 & $\mathrm{CO}+4 \mathrm{H}_{2} \rightarrow \mathrm{CH}_{4}+2 \mathrm{H}_{2} \mathrm{O}$ & \\
Steam Reforming Reactions & & $+206 \mathrm{~kJ} / \mathrm{mol}$ \\
R12 & $\mathrm{CH}_{4}+\mathrm{H}_{2} \mathrm{O} \leftrightarrow \mathrm{CO}^{2}+3 \mathrm{H}_{2}$ & $-36 \mathrm{~kJ} / \mathrm{mol}$ \\
R13 & $\mathrm{CH}_{4}+0.5 \mathrm{O}_{2} \rightarrow \mathrm{CO}^{2}+2 \mathrm{H}_{2}$ & \\
\hline
\end{tabular}

Obviously, the reactions that occur are not limited to the reactions described in Table 1. There are also insignificant by-product components, such as $\mathrm{H}_{2} \mathrm{~S}, \mathrm{SO}_{\mathrm{x}}, \mathrm{NH}_{3}$, and $\mathrm{NO}_{\mathrm{x}}$ regarding the sulfur content of coal and nitrogen in biomass. The gasification process is divided into several types according to the type of gasification reactor and the hydrodynamic flow of gas in the reactor. The division of this type of gasification reactor is explained in Figure 4.

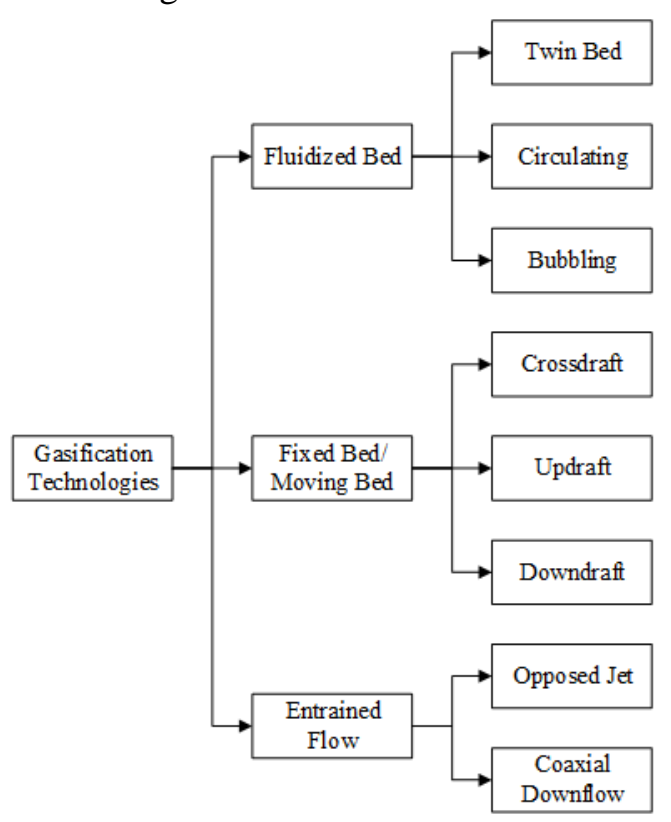

Figure 4. Gasification technologies and reactor types (Basu, 2013a).

Each type of gasification reactors shows main requirements in aspects of the type of material used as feed, feed material size, reaction temperature, reaction pressure, output gas temperature, oxygen demand, steam demand, capacity, ash phase, and product gas composition (Basu, 2013a; Hardianto et al., 2015). In this case, the main factors examined in this paper are the type of feed material and product gas composition. A comparison of these two parameters is presented in Table 2. 
Table 2. Gasification technologies general characterization.

\begin{tabular}{|c|c|c|c|c|}
\hline Parameters & Fixed/ Moving Bed & Fluidized Bed & Entrained Bed & Source \\
\hline Feedstock & Low-rank coal & $\begin{array}{l}\text { Low-rank coal and } \\
\text { excellent for } \\
\text { biomass }\end{array}$ & $\begin{array}{l}\text { All type of coal but } \\
\text { unsuitable for biomass }\end{array}$ & $\begin{array}{l}\text { (Basu, } \\
\text { 2013a) }\end{array}$ \\
\hline $\begin{array}{l}\text { Product gas } \\
\text { concentration } \\
\text { (percentage in } \\
\text { moles) }\end{array}$ & $\begin{array}{l}\mathrm{H}_{2}=41-43 \% \\
\mathrm{CO}=14-16 \% \\
\mathrm{CH}_{4}=8-9 \% \\
\mathrm{CO}_{2}=30-32 \%\end{array}$ & $\begin{array}{l}\mathrm{H}_{2}=6-37 \% \\
\mathrm{CO}=30-58 \% \\
\mathrm{CH}_{4}=1-4 \% \\
\mathrm{CO}_{2}=2-13 \%\end{array}$ & $\begin{array}{l}\mathrm{H}_{2}=28-34 \% \\
\mathrm{CO}=26-57 \% \\
\mathrm{CH}_{4}=0.04-0.5 \% \\
\mathrm{CO}_{2}=2-16 \%\end{array}$ & $\begin{array}{l}\text { (Hardianto } \\
\text { et al., } \\
\text { 2015) }\end{array}$ \\
\hline
\end{tabular}

Based on Table 2, it can be seen that the Fixed Bed/Moving Bed and Fluidized Bed type gasification reactors are suitable for biomass utilization with the most suitable use of biomass in the Fluidized Bed reactor type while the biomass utilization in the Entrained Bed reactor is not suitable. However, all types of reactors show compatibility for low rank coal utilization. Another difference can be seen from the aspect of the constituent gas component content which is different for each type of gasification technology used. Some literatures explain the possibility of using coal and biomass together. This technology is known as co-gasification technology. In this technology, there are stages of preparation for each coal and biomass before it can be used together. In addition, ash or alkali content present in biomass catalyses the gasification of coal. The types of reactors used in researching the efficiency of cogasification technology include Fixed Bed and Fluidized Bed (Brar et al., 2012). There are several kinds of gasification to be reviewed in this chapter. They consist of low rank coal gasification, biomass gasification, and co-gasification of coal and biomass.

\subsection{Low Rank Coal Gasification}

Several studies were conducted specifically to determine the performance of low rank coal gasification. This research is basically carried out in accordance with the abundance of low rank coal due to the significant utilization of middle-class coal. Low rank coal (lignite and sub-bituminous) has lower heating value, higher water content, and volatile matter compared to other coals. The main parameters studied are generally the effects of temperature, pressure, steam $/ \mathrm{O}_{2}$ ratio, and steam/coal ratio. Optimum gas quality is obtained at a temperature of $600-700{ }^{\circ} \mathrm{C}$ with the highest difference in $\mathrm{H}_{2}$ concentration than $\mathrm{CO}$ in syngas which gives the highest $\mathrm{H}_{2} / \mathrm{CO}$ ratio. Meanwhile, an increase in the steam/coal ratio and the steam $/ \mathrm{O}_{2}$ ratio are reported to improve the quality of syngas (Hardianto et al., 2015; Karimipour et al., 2013). In addition to these parameters, there are other studies that analyze the effect of $\mathrm{O}_{2} / \mathrm{C}$ molar ratios on gasification performance and syngas quality (Zhang et al., 2016). The results of the study are shown in Figure 5.
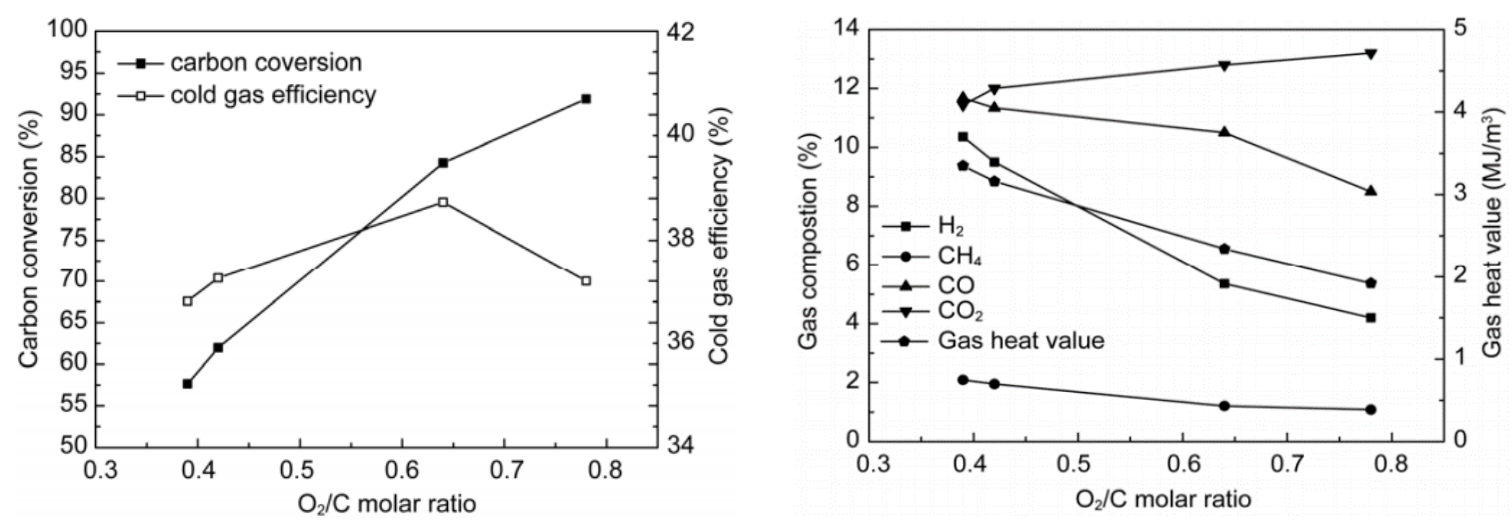

Figure 5. The effect of $\mathrm{O}_{2} / \mathrm{C}$ molar ratio to low rank coal gasification performance (Zhang et al., 2016).

Based on Figure 5, an increase in oxygen concentration is proportional to an increase in carbon conversion. This is because less coal reacts with oxygen and causes an increase in carbon conversion. However, an increase in oxygen concentration causes a decrease in the $\mathrm{H}_{2} / \mathrm{CO}$ ratio and a decrease in 
the content of the two main gases of syngas. On the other hand, it appears that $\mathrm{CO}_{2}$ concentrations have increased due to the presence of excess $\mathrm{O}_{2}$ which causes further $\mathrm{CO}$ oxidation reactions (Zhang et al., 2016).

\subsection{Biomass Gasification}

Biomass gasification is an important thing to implement, especially for countries that have large natural plant resources such as Indonesia. Biomass can be gasified because it is also a carbonaceous material. However, drying pretreatment is needed to reduce the water content so that it can optimize the efficiency of gasification performance. One study provides an overview of the comparative efficiency of gasification for several types of biomass used as gasifier feedstock. The comparison is presented in Figure 6.

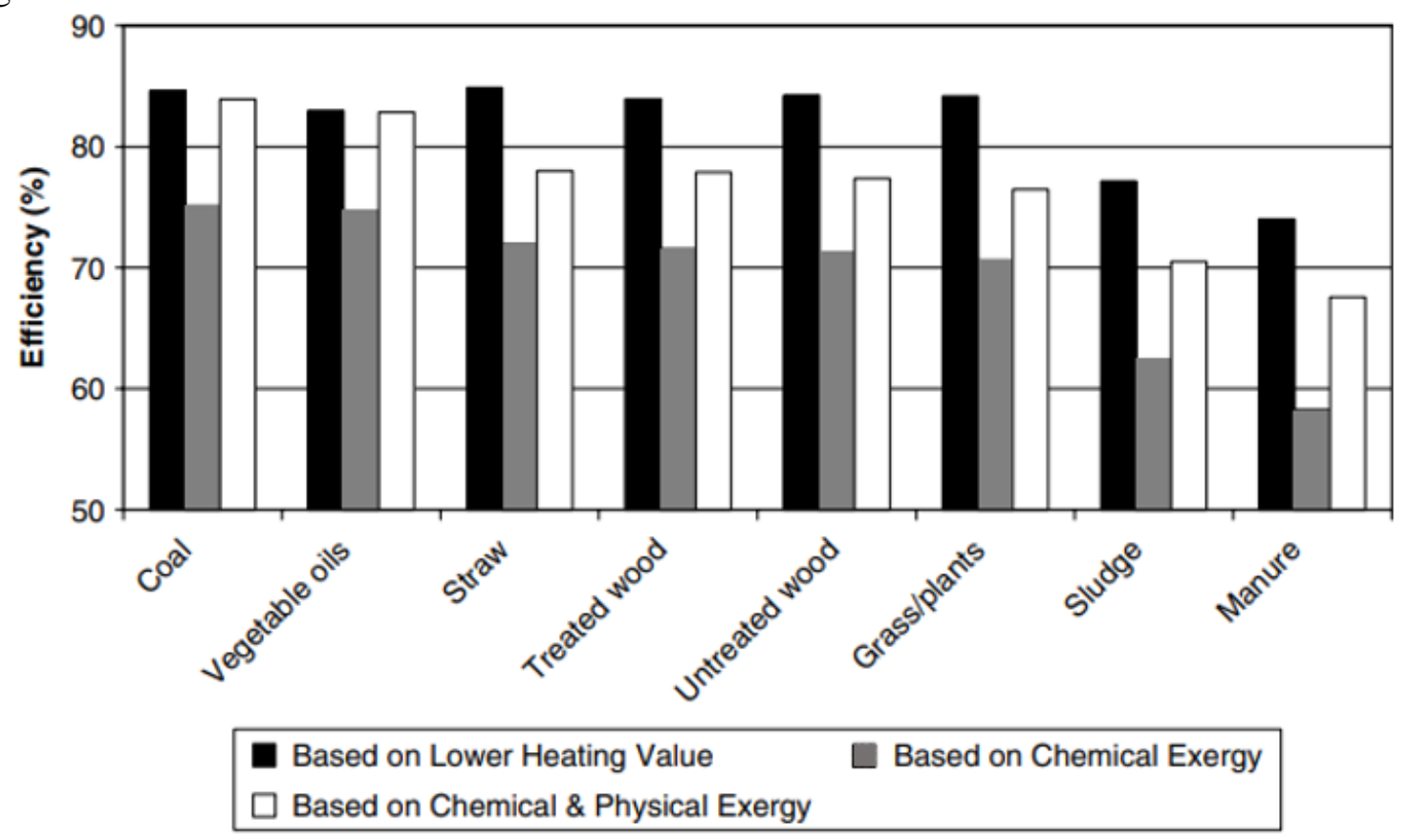

Figure 6. Gasification efficiency according to the types of feedstocks (Ptasinski, 2008).

Figure 6 shows the energetic and exergetic efficiencies for the gasification of the biomass. The energetic efficiencies of vegetable oil, straw, treated wood, untreated wood and grass are comparable with coal, whereas efficiencies for sludge and manure are considerably lower (Ptasinski, 2008). One of the biomass gasification studies gives an average yield of several parameters studied in the resulting syngas property. These results are explained in Table 3. 
Table 3. Syngas characterization from various biomass gasification (Susanto, Suria, \& Pranolo, 2018; Wei et al., 2009).

\begin{tabular}{|c|c|c|c|c|c|}
\hline \multirow[b]{2}{*}{ Parameter } & \multicolumn{4}{|c|}{ Average Value } & \multirow[b]{2}{*}{ Unit } \\
\hline & $\begin{array}{l}\text { Hardwood } \\
\text { Chips }\end{array}$ & $\begin{array}{l}\text { Coconut } \\
\text { Shell }\end{array}$ & $\begin{array}{c}\text { Rubber } \\
\text { Wood }\end{array}$ & Rice Husk & \\
\hline Biomass Conversion Rate & 2.37 & - & - & - & $\mathrm{Nm}^{3} / \mathrm{kg}$ \\
\hline Carbon Conversion Rate & 98.01 & - & - & - & $\%$-weight \\
\hline $\mathrm{H}_{2}$ & 17.55 & 12 & 16 & 11 & $\%$-volume \\
\hline $\mathrm{CO}$ & 22.16 & 25 & 18 & 20 & $\%$-volume \\
\hline $\mathrm{CO}_{2}$ & 11.89 & 10 & 10 & 11 & $\%$-volume \\
\hline $\mathrm{CH}_{4}$ & 3.07 & 1 & 2 & 2 & $\%$-volume \\
\hline $\mathrm{N}_{2}$ & 45.33 & 52 & 54 & 56 & $\%$-volume \\
\hline LHV & 5.79 & 4.9 & 4.6 & 4.35 & $\mathrm{MJ} / \mathrm{Nm}^{3}$ \\
\hline $\mathrm{H}_{2} / \mathrm{CO}$ Ratio & 0.79 & 0.48 & 0.89 & 0.55 & - \\
\hline
\end{tabular}

Based on Table 3, the Biomass Conversion Rate parameter indicates a comparison of the resulting syngas yield relative to the mass unit of hardwood chip biomass that is fed. Both biomass and carbon conversion rate values can be said to be high in this study. In addition, the syngas composition resulting from hardwood chips biomass gasification produced an $\mathrm{H}_{2} / \mathrm{CO}$ ratio of around 0.8 . However, there is still some $\mathrm{CO}_{2}$ produced as a by-product at $11.89 \%$-volume (Wei et al., 2009). The same thing is also found for other biomass, namely coconut shell, rubber wood, and rice husk which is a biomass waste that is widely produced in Indonesia. Indonesian biomass waste that produces the most $\mathrm{H}_{2}$ is rubber wood with the highest $\mathrm{H}_{2} / \mathrm{CO}$ ratio of 0.9 (Susanto et al., 2018).

\subsection{Coal and Biomass Co-gasification}

Research related to co-gasification technology was also conducted to determine the effect of adding biomass to the coal gasification system on carbon conversion and syngas quality. The study was conducted using PRB coal and biomass which types is not mentioned (Chen et al., 2011). The results of the study are shown in Figure 7.
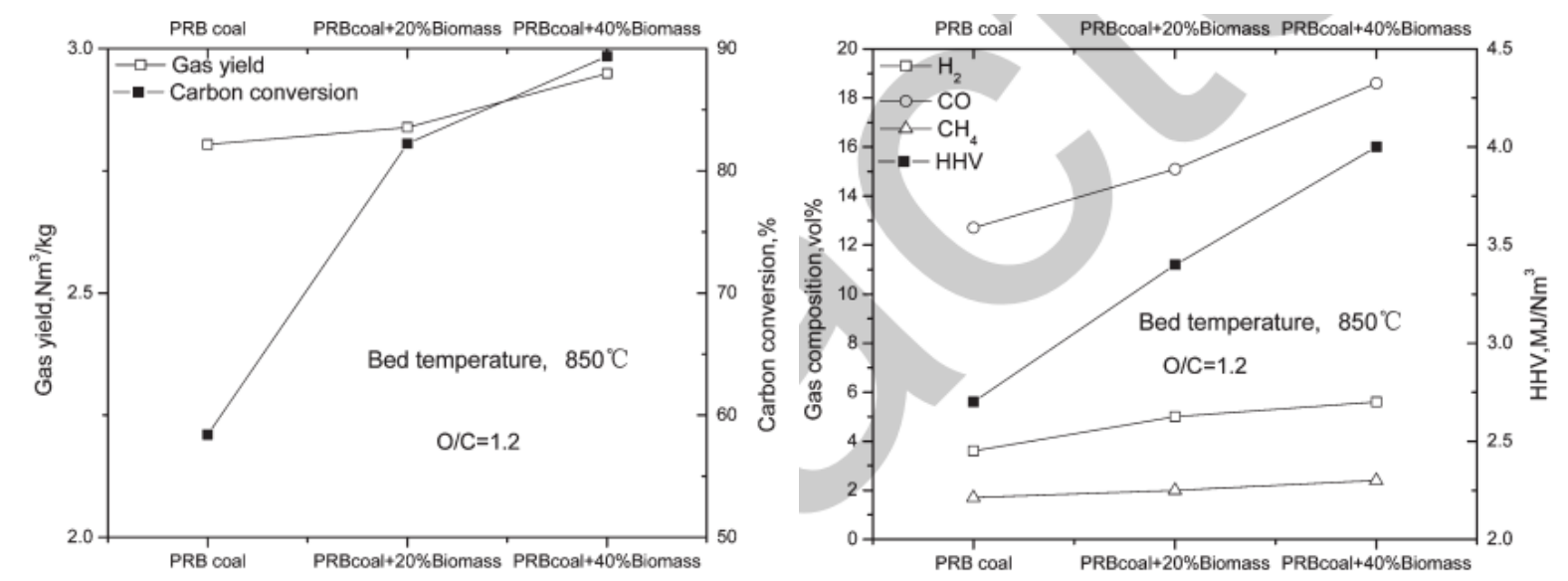

Figure 7. The effect of biomass addition to the gasification performance (Chen et al., 2011).

Based on Figure 7, the gradual addition of biomass can significantly increase carbon conversion and syngas acquisition as well as increase HHV from the product gas. In composition, the addition of biomass can increase $\mathrm{H}_{2}$ and $\mathrm{CO}$ content. However, an increase in $\mathrm{CO}$ content which is much faster than the increase in $\mathrm{H}_{2}$ content causes a decrease in $\mathrm{H}_{2} / \mathrm{CO}$ ratio in the produced syngas (Chen et al., 2011). 


\section{3. $\mathrm{CO}_{2}$ Capture System Using Calcium Looping HyPr-RING Process Technology}

Carbon dioxide is a common side product in coal gasification technology that is considered a pollutant to the environment and is targeted to decrease by $29 \%$ in 2030 . Therefore, a carbon capture technology is necessary to help reduce $\mathrm{CO}_{2}$ gases in coal utilization. Calcium looping, which is a cycling calcium oxide $(\mathrm{CaO})$-calcium carbonate $\left(\mathrm{CaCO}_{3}\right)$ process is an option being developed for large-scale $\mathrm{CO}_{2}$ control. $\mathrm{CaO}$ or $\mathrm{Ca}(\mathrm{OH})_{2}$ captures $\mathrm{CO}_{2}$ during coal gasification to form $\mathrm{CaCO}_{3}$ and releases heat for gasification to produce hydrogen in one gasifier (Lin et al., 2011). In HyPr-RING process, $\mathrm{CaO}$ is used as $\mathrm{CO}_{2}$ sorbent and is directly injected into the gasifier with steam. The scheme for the calcium looping system with HyPr-RING process is shown in Figure 8.

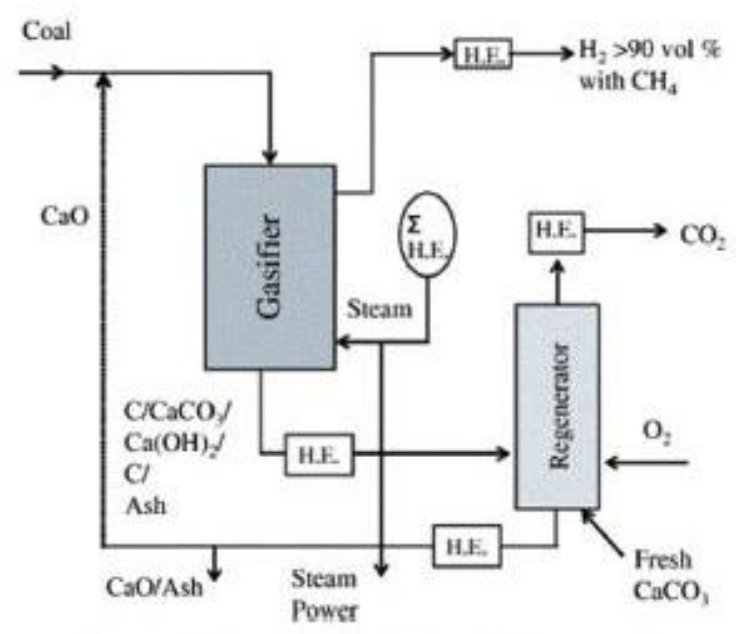

Figure 8. Scheme for calcium looping system to capture $\mathrm{CO}_{2}$ (Lin, 2011).

There are two places in which $\mathrm{CaO}$ is used during the calcium looping process, including gasifier and calciner. On the gasifier, coal gasifies with steam to form $\mathrm{CO}$ and $\mathrm{H}_{2}$, and the $\mathrm{CaO}$ reacts with the $\mathrm{CO}$ from the syngas to form $\mathrm{CaCO}_{3}$ as well as extra $\mathrm{H}_{2} . \mathrm{H}_{2}$ is the major gas that is produced in the gasifier and the $\mathrm{CO}_{2}$ that are produced will be reduced using the $\mathrm{CaO}$ injected and is converted into $\mathrm{CaCO}_{3}(\mathrm{Lin}$, 2013). The four main reactions integrated in the gasifier are shown in Equation (1)-(4). The overall reaction of the equations that take place in the gasifier is presented in Equation (5).

$$
\begin{array}{ll}
\mathrm{CaO}+\mathrm{H}_{2} \mathrm{O} \rightarrow \mathrm{Ca}(\mathrm{OH})_{2} & \Delta H^{{ }}{ }_{298}=-109 \mathrm{~kJ} / \mathrm{mol} \\
\mathrm{C}+\mathrm{H}_{2} \mathrm{O} \rightarrow \mathrm{CO}+\mathrm{H}_{2} & \Delta H^{{ }}{ }_{298}=+132 \mathrm{~kJ} / \mathrm{mol} \\
\mathrm{CO}+\mathrm{H}_{2} \mathrm{O} \rightarrow \mathrm{CO}_{2}+\mathrm{H}_{2} & \Delta H^{{ }^{\circ}}{ }_{298}=-41.5 \mathrm{~kJ} / \mathrm{mol} \\
\mathrm{Ca}(\mathrm{OH})_{2}+\mathrm{CO}_{2} \rightarrow \mathrm{CaCO}_{3}+\mathrm{H}_{2} \mathrm{O} & \Delta H^{{ }}{ }_{298}=-69 \mathrm{~kJ} / \mathrm{mol} \\
\mathrm{C}+2 \mathrm{H}_{2} \mathrm{O}+\mathrm{CaO} \rightarrow \mathrm{CaCO}_{3}+2 \mathrm{H}_{2} & \Delta H^{{ }}{ }_{298}=-88 \mathrm{~kJ} / \mathrm{mol}
\end{array}
$$

Through the overall reaction, the main phenomenon of this method is seen where 1 mole of carbon can produce 2 moles of hydrogen. This is based on the fact that more than $91 \%$-volume of $\mathrm{H}_{2}$ is produced in the final product gas and is an advantage of this method. Through the process of calcination, the $\mathrm{CaCO}_{3}$ resulting from the conversion of $\mathrm{CO}_{2}$ using $\mathrm{CaO}$ will be regenerated back into $\mathrm{CaO}$. Heat is needed for the process of calcination, but fortunately, some of the heat will be reused again from the coal gasification process, making it highly energy efficient (Lin et al., 2011). The reaction that occurs in the calciner is shown in Equation 6.

$$
\mathrm{CaCO}_{3} \mathrm{CaO}+\mathrm{CO}_{2} ; \quad \Delta H^{2}{ }_{298}=+178 \mathrm{~kJ} / \mathrm{mol}
$$


The concept and operational condition of calcium looping system is shown in Figure 9. This $\mathrm{CO}_{2}$ capture technology has several advantages, including high efficiency of $\mathrm{CO}_{2}$ removal, ability to utilize low-ranked coal, affordable material, and removes sulfur in gasifier (Lin, 2013). Moreover, calcium looping is specifically used to increase the yield of $\mathrm{H}_{2}$ production in the gasification process, thus increasing the quality of syngas.

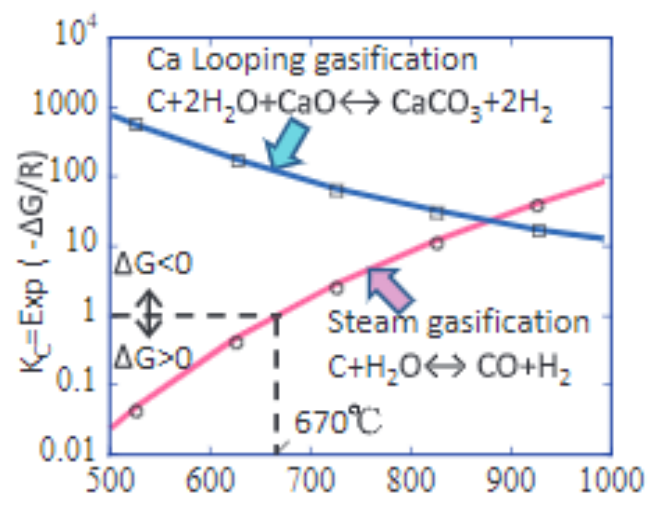

\section{Reaction constants vs. temperature}

Figure 9. Operational condition of calcium looping (Lin, 2013).

Continuation research has shown various main results that show the effect of HyPr-RING process as an alternative to capture $\mathrm{CO}_{2}$ and increase the production of $\mathrm{H}_{2}$ in gasification technology. Figure 10 shows the experimental results that are obtained in the gasifier and calciner when HyPr-RING process is implemented.

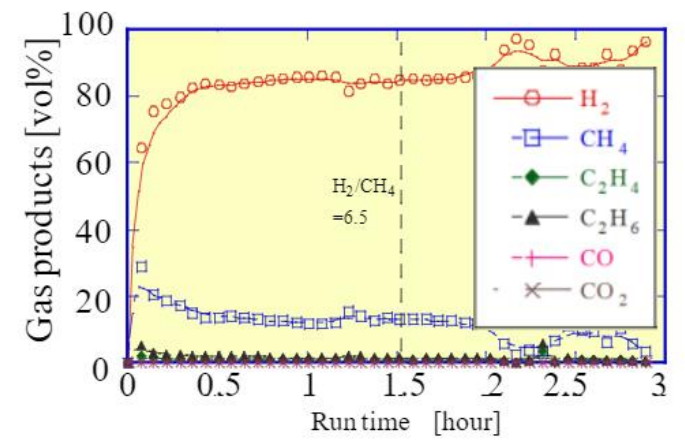

Composition of gasification gases

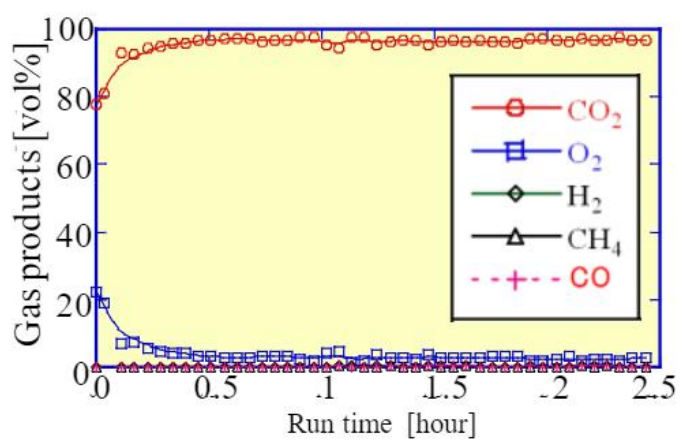

Composition of calcinations gases

Figure 10. Experimental results of gasifier and calciner product gases (Lin et al., 2011).

Based on the experimental results shown in Figure 10, the product of fuel gas that is obtained contains $91 \%$ volume of $\mathrm{H}_{2}$ and $9 \%$ volume of $\mathrm{CH}_{4}$ at $923 \mathrm{~K}$ and $3.0 \mathrm{MPa}$. The cold gas efficiency resulting from the process reaches $77 \%$ (Lin et al., 2011). $\mathrm{CaO}$ used as the $\mathrm{CO}_{2}$ sorbent also helps improve tar steam reforming process. Moreover, ash and sulfur compounds that are acquired can be separated using an extra equipment such as cyclone (Lin, 2013). 


\section{Material and Economic Feasibility of Low Rank Coal and Biomass Co-gasification Technology in Indonesia for Future Application}

\subsection{Material Feasibility}

Since the feedstock for coal gasification process varies from biomass to low-ranked coal, the area which produces these feedstocks also varies. Analyzing the abundance of potential biomass in Indonesia, there are three major areas which produce a huge number of rubber, palm oil, and rice. The distribution of potential biomass in Indonesia can be seen in Table 4.

Table 4. Top 3 biomass productivity in Indonesia.

\begin{tabular}{llll}
\hline \multicolumn{1}{c}{ Type of Biomass } & \multicolumn{1}{c}{ Production (in 2018) } & \multicolumn{1}{c}{ Location } & Production Quantity \\
\hline Rubber Wood & 3.63 million tons & South Sumatera & 997,000 tons \\
Palm Oil & 34.50 million tons & South Kalimantan & 2.20 million tons \\
Rice & 56.54 million tons & Central Java & 9.61 million tons \\
\hline
\end{tabular}

Based on biomass availability analysis from Agricultural Statistic 2018, waste of empty palm bunches will be as much as $21 \%$ of the palm oil production, rice husk waste will be as much as $20 \%$ of rice production, and rubber wood waste will be as much as $18 \%$ of the rubber wood production. This statistical data shows how Indonesia has a huge potential of waste biomass that can be further utilized and converted into higher valuable products.

Together with the high potential of biomass waste production stated above, Indonesia still produces a vast amount of coal which is predominated by low-ranked coal. Out of all the provinces in Indonesia, Sumatra and Kalimantan island have the highest potential of coal production resources, contributing $52,483.20$ and 52,326.23 million tons, respectively (Stanford, 2013). The production of coal for each company is shown in Table 5.

Table 5. Indonesian coal resources and reserves by province in 2018 (Stanford, 2013).

\begin{tabular}{ll}
\hline \multicolumn{1}{c}{ Company } & \multicolumn{1}{c}{ Total Production (million tons) } \\
\hline Kaltim Prima Coal & 60 \\
Adaro Indonesia & 50 \\
Berau Coal & 33 \\
Kideco Jaya Agung & 32 \\
Arutmin Indonesia & 28.8 \\
Bukit Asam & 25.5 \\
Borneo Indobara & 17.3 \\
Indominco Mandiri & 13 \\
Antang Gunung Merantus & 7.7 \\
Indexim Colaindo & 6 \\
\hline
\end{tabular}

Furthermore, for the calcium looping process, since $\mathrm{CaO}$ is not available in bulk, the most feasible material to use is $\mathrm{CaCO}_{3}$ or limestone. $\mathrm{CaCO}_{3}$ resources in Indonesia is large, accumulating up to 2,156 billion tons. This resource is dispersed and varies in locations ranging from South East Sulawesi as the highest contributor (1,527 million tons) to Papua as the lowest contributor (2.6 million tons) (Aziz, 2010). The abundant resources of feedstock materials such as coal, biomass, and limestone increase the possibility of the implementation of coal gasification technology with carbon capture system.

\subsection{Economic Feasibility}

According to recent research, coal gasification technology in Indonesia has high economic feasibility as it is proven to be profitable. The total CAPEX for coal gasification implementation for syngas generation is USD 42,834 while the OPEX reaches USD 13,332. Calculating all of the available parameters necessary in implementing coal gasification technology for syngas generation, the net profit 
over total live of project (20 years) reaches up to USD 58,215. Moreover, the calculated rate of return on investment (ROI) is $11 \%$, while the discounted cash flow rate of return (DCFROR/ IRR) is $5.49 \%$. These numbers resulted in a breakeven point (BEP) of $40 \%$ (Zuldian et al., 2017).

\section{Conclusion}

In order to achieve energy security and fulfill the increasing energy demand in Indonesia, utilization of energy sources that are extremely abundant such as coal reserves (especially low-ranked coal with a potential of 22.6 billion tons) and biomass waste (32.6 GW potential) is necessary. One major technology that is seen to bring such potential is gasification. Gasification is a process for converting all types of carbon-based materials such as biomass and coal into synthetic gas that have chemical heat values through partial oxidation. Although it is considered to be a clean process, gasification still emits a small amount of $\mathrm{CO}_{2}$. Therefore, a carbon capture technology called HyPr-RING process is implemented, which uses $\mathrm{CaO}$ to reduce $\mathrm{CO}_{2}$ and increase the quality of syngas by increasing $\mathrm{H}_{2}$ content up to $91 \%$-volume. Application of this technology is not only economically feasible and profitable (ROI of $11 \%$ and BEP of $40 \%$ ), but it is also feasible in terms of materials and feedstock as Indonesia owns around 10 companies that produce a high number of coal and various resources of biomass. Through various research and analysis of the gasification method with carbon capture technology, coal and biomass are believed to be a reliable source to achieve energy security in Indonesia.

\section{References}

Aziz, M. (2010). Batu kapur dan peningkatan nilai tambah serta spesifikasi untuk industri. Jurnal Teknologi Mineral Dan Batubara, 3(6), 116-131.

Basu, P. (2013a). Design of biomass gasifiers. Biomass Gasification, Pyrolysis and Torrefaction. https://doi.org/10.1016/b978-0-12-396488-5.00008-3

Basu, P. (2013b). Gasification theory. Biomass Gasification, Pyrolysis and Torrefaction. https://doi.org/10.1016/b978-0-12-396488-5.00007-1

Brar, J. S., Singh, K., Wang, J., \& Kumar, S. (2012). Cogasification of coal and biomass: A review. International Journal of Forestry Research, 2012, 1-10. https://doi.org/10.1155/2012/363058

Chen, G., Zhang, Y., Zhu, J., Cao, Y., \& Pan, W. (2011). Coal and biomass partial gasification and soot properties in an atmospheric fluidized bed. Energy and Fuels, 25(5), 1964-1969. https://doi.org/10.1021/ef101754v

Gielen, D., Saygin, D., \& Rigter, J. (2017). Renewable energy prospects: Indonesia, a RE map analysis. International Renewable Energy Agency (IRENA).https://doi.org/10.1145/347642.347800

Guan, G. (2017). Clean coal technologies in Japan: A review. Chinese Journal of Chemical Engineering, 25(6), 689-697. https://doi.org/10.1016/j.cjche.2016.12.008

Hardianto, T., Amalia, A. R., Suwono, A., \& Riauwindu, P. (2015). Study of Indonesia low rank coal utilization on modified fixed bed gasification for combined cycle power plant. IOP Conference Series: Materials Science and Engineering, 88(1). https://doi.org/10.1088/1757-899X/88/1/012042

Karimipour, S., Gerspacher, R., Gupta, R., \& Spiteri, R. J. (2013). Study of factors affecting syngas quality and their interactions in fluidized bed gasification of lignite coal. Fuel, 103, 308-320. https://doi.org/10.1016/j.fuel.2012.06.052

Kementerian Energi dan Sumber Daya Mineral. (2016). Data Inventory Emisi GRK Sektor Energi. https://www.esdm.go.id/assets/media/content/content-data-inventory-emisi-grk-sektor-energi-.pdf

Lin, S. (2013). Development of in-situ $\mathrm{CO}_{2}$ capture coal utilization technologies. Energy Procedia, 37, 99-106. https://doi.org/10.1016/j.egypro.2013.05.089

Lin, S., Kiga, T., Nakayama, K., \& Suzuki, Y. (2011). Coal power generation with in-situ $\mathrm{CO}_{2}$ captureHyPr-RING method: Effect of ash separation on plant efficiency. Energy Procedia, 4, 378-384. https://doi.org/10.1016/j.egypro.2011.01.065

Pereira, E. G., Da Silva, J. N., De Oliveira, J. L., \& MacHado, C. S. (2012). Sustainable energy: A review of gasification technologies. Renewable and Sustainable Energy Reviews, 16(7), 4753-4762. https://doi.org/10.1016/j.rser.2012.04.023 
Ptasinski, K. J. (2008). Thermodynamic efficiency of biomass gasification and biofuels conversion. Biofuels, Bioproducts and Biorefining, 2, 239-253. https://doi.org/10.1002/bbb.65

Purohit, P. (2009). Economic potential of biomass gasification projects under clean development mechanism in India. Journal of Cleaner Production, 17(2), 181-193. https://doi.org/10.1016/j.jclepro.2008.04.004

RUEN. (2017). Perpres 22/2017_RUEN. 6. https://www.esdm.go.id/assets/media/content/contentrencana-umum-energi-nasional-ruen.pdf

Stanford, C. E. (2013). Coal resources, production and use in Indonesia. The Coal Handbook: Towards Cleaner Production, 2. https://doi.org/10.1533/9781782421177.2.200

Suharyati, Pambudi, S. H., Wibowo, J. L., \& Pratiwi, N. I. (2019). Indonesia Energy Outlook 2019 (Vol. 1). https://doi.org/ISSN 2527-3000

Susanto, H., Suria, T., \& Pranolo, S. H. (2018). Economic analysis of biomass gasification for generating electricity in rural areas in Indonesia. IOP Conference Series: Materials Science and Engineering, 334(1). https://doi.org/10.1088/1757-899X/334/1/012012

Tun, M. M., Juchelkova, D., Win, M. M., Thu, A. M., \& Puchor, T. (2019). Biomass energy: An overview of biomass sources, energy potential, and management in Southeast Asian countries. Resources, 8(2). https://doi.org/10.3390/resources8020081

Wei, L., Thomasson, J. A., Bricka, R. M., Sui, R., Wooten, J. R., \& Columbus, E. P. (2009). Syn-gas quality evaluation for biomass gasification with a downdraft gasifier. Transactions of the ASABE, 52(1), 21-37.

Zhang, H., Zhang, Y., Zhu, Z., \& Lu, Q. (2016). Circulating fluidized bed gasification of low rank coal: Influence of $\mathrm{O} 2 / \mathrm{C}$ molar ratio on gasification performance and sulphur transformation. Journal of Thermal Science, 25(4), 363-371. https://doi.org/10.1007/s11630-016-0872-9

Zuldian, P., Fukuda, S., \& Bustan, M. D. (2017). Economic analysis of coal gasification plant for electricity and thermal energy supplies in Indonesia. Journal of Clean Energy Technologies, 5(3), 193-198. https://doi.org/10.18178/jocet.2017.5.3.368 